\title{
In Service Teacher Development Using ICT: First Step in Lifelong Learning
}

\author{
José Armando Valente \\ Department of Multimidia and Nucleus of Informatics Applied to Education (NIED) - \\ UNICAMP, Graduate School of Education Curriculum - PUCSP, Brazil, jvalente@unicamp.br
}

\begin{abstract}
What should the teacher of the future be? Among other things this professional should be able to practice and promote the development of lifelong learning skills. The question is how to prepare teachers to be able to reach this goal.

The process of preparing teachers to use ICT in their pedagogical activities, carried out in two main courses in Brazil, is an attempt to move in this direction. These are on-line courses on the Internet, designed to prepare teachers respectively from special education, and from basic education, to be able to use ICT in their classroom activities. These courses use the virtual being together approach to Distance Education, promoting the development of the reflective teacher, emphasizing reflection-in-action and reflection-onaction and working with contextualized and decontextualized knowledge.
\end{abstract}

Since the course emphasizes the development of reflective teachers and provides a means for them to understand ICT activities as windows into peoples' thinking processes, teachers are acquiring ways to interact with their students, discussing the concepts involved in their activities as well as how knowledge is constructed. These are the first steps in mastering important ideas about how to become lifelong learners and how to create learning situations to help their students to develop lifelong learning mindsets.

\section{INTRODUCTION}

The increasing amount of information available today and the need to know how to process and attribute meaning to it indicates that we are living in an intensive knowledge-based economy. In this new economy people need to be critical, creative, with the capacity to think, to make decisions, and to solve problems. In fact, these are the most desired characteristics indicated

The original version of this chapter was revised: The copyright line was incorrect. This has been corrected. The Erratum to this chapter is available at DOI: 10.1007/978-0-387-35701-0_35 
by owners or high executives of 1,500 industries (small, medium and big), in the São Paulo state, Brazil, in a survey conducted by the University of São Paulo (USP) in 1998, as part of the study "Engineers of New Times" (Engenheiro dos Novos Tempos). The six most desirable characteristics listed were: the ability to work in teams, commitment to the quality of what is done, the ability to live with changes, the ability to take initiative in decision making, a clear vision of the client-producer's role, and the ability to use knowledge of information technology.

From this list it is clear that professionals in the knowledge-based economy must learn how to learn, to deal with an increasing number of information sources and to collaborate with people locally or around the world by using new information tools. The emergence of a knowledge-based society is demanding a more comprehensive framework for human resource development, and human development is becoming too important and diverse to be left only for schools. Changes are taking place so fast that it is unthinkable that teachers and the school can provide all the knowledge we need in our lifetime. People should become lifelong learners and schools have an important role in helping them to develop lifelong learning skills. This applies to everybody, including teachers and students.

However, schools and teachers have to be prepared to cope with these changes. Providing more of the same traditional education that emphasizes transmission and memorization of information will not contribute to solving the human development bottleneck. The kind of "education" necessary in order to be effective in the knowledge economy should be one that leads to learning as a process of constructing knowledge of concepts, of strategies about how to use these concepts in problem solving, as well as of how to learn.

One of the solutions schools have adopted to change their educational approach is the introduction of information and communication technology (ICT) as a pedagogical tool. Similar to what has happened in other sectors of society, the introduction of these technologies implies changing certain procedures and the preparation of people to be able to explore the resources ICT provides.

Regarding the preparation of teachers to be able to use ICT in their practice, there are two different solutions that have to be implemented. One is the preparation of undergraduate students who are going to be teachers. The other is the preparation of teachers who are already working in schools. The work that is described in this article is related to the latter situation.

The preparation of teachers already in the classroom poses interesting problems, especially in large countries as Brazil, with about 1.2 million teachers. The solution that has been adopted is in-service training courses, via the Internet, using the ICT facilities that are being installed in schools. 
These courses have the advantage of keeping teachers in their work settings, of using the technology available in the school, of helping teachers to solve idiosyncratic problems they find in their school that prevent the integration of ICT into their practice, and of helping teachers not only to acquire knowledge about ICT but also about learning to become lifelong learners. The main objective of these courses is to convey a construction of knowledge mindset and an understanding of how ICT can help students and teachers in this process.

ICT can play two fundamental roles as a learning tool: to make thinking processes explicit and to allow the establishment of a virtual learning network. In the first, computer activities create a window into the learner's mind (Valente, 1995a; Weir, 1987) so the teacher can engage and interact with the student in a Socratic mode to discuss her/his knowledge construction; in the latter people are allowed to present and discuss via the Internet the product of their learning process with a larger audience and with depth that is almost impossible to do in a face-to-face situation. In both cases, the objective is to help people to become better learners and to give them tools to become lifelong learners.

\section{ICT ACTIVITIES AS WINDOWS INTO THE LEARNER'S MIND}

ICT can be used in education in many different ways. It can be used to help students to acquire information, as a way to deliver information in an organized way, such as is achieved with tutorials, or to present tasks to be solved by the student and automatically corrected. In all these ICT has been used to enhance the teaching process in the sense that it can help fill up the learners' mind with information - a computer version of the banking approach to education, as pointed out by Paulo Freire (Freire, 1975).

However, ICT can do much more than this. It can function as media to be filled with information by the learner as s/he uses these technologies to solve problems. Now the learner has to use the knowledge $\mathrm{s} / \mathrm{he}$ has in order to instruct the ICT about how to solve a particular task, making explicit what s/he knows. In this sense, ICT activities become a window into the learner's thinking and knowledge. In order for this to happen, the learner has to use open-ended software such as programming languages, word processors, spreadsheets, systems to create database, or systems to construct Web pages. This way, ICT presents important features, functioning as tools for students to construct new knowledge. 
The analysis of computer activities using open-ended software (Valente, 1999a) shows that the user-computer interaction can be seen in terms of a sequence of actions - description-execution-reflection-debuggingdescription, each having an important role in the process of acquiring knowledge such as:

- Description of the problem solution using the learner's knowledge (concepts involved in the problem, concepts about the computer and about the software, and strategies about how to apply these concepts) to represent and describe steps of the problem solution in terms of the software;

- Execution of this description by the computer, producing immediate and accurate feedback;

- Reflection on results given by the computer, leading the learner to compare what was achieved with the originally intended ideas and to take one of the following alternative actions: do nothing, since the problem is considered resolved; or debugging the description, since the result is different from what was intended;

- Debugging the learner's original description by thinking over or searching for new information. Once the description is changed, the sequence description-execution-reflection-debugging-description can be repeated.

However, the description-execution-reflection-debugging actions do not happen by simply putting the learners in front of the computer. A teacher who knows a great deal about how to foster learning - a learning agent must mediate the learner-computer interaction. In addition, the learner is a social being and is part of a social and cultural environment that can be a source of ideas and information, or a place to find projects to be solved.

The sequence of actions description-execution-reflection-debugging provides important ingredients for the knowledge construction process. First, it shows the importance of description and execution. What the learner passes to the computer is an explicit expression of her/his reasoning, in terms of a specific piece of software. However, it is not enough to describe thinking. It is necessary to execute it. In this sense, it is as if the computer were executing the learner's thinking. The immediate and reliable feedback allows the confrontation of the learner's original ideas with the results obtained by the computer and this comparison is the first step in the

${ }^{1}$ Debugging is a term introduced by Artificial Intelligence (Sussman, 1975), meaning the process of eliminating "bugs" that prevent computer programs from working. In this case, programmers do not ask whether the program is correct or wrong but if it has bugs and if is possible to fix it or "debug" it. Bug and debugging were adopted by Papert (1980) as a way of looking at intellectual activities as having bugs rather than errors for which to be punished. 
reflective process, to be aware of what s/he knows and what should be debugged.

Second, reflection and debugging are engines of the construction of different types of knowledge process. While reflecting, the learner has to think about the development of the project, concepts and strategies. If necessary, s/he has to look for new information, transform it into knowledge and apply it to improve the original problem description, thus creating opportunities to discuss the strategies used to develop the project, about concepts involved in the project and about learning strategies. All these are facilitated by the existence of the problem description, making possible the analysis of the problem solution so the learner can find her/his mistakes (bugs) and the teacher can understand what the learner is doing and thinking.

Thus, each of these actions creates opportunities to increment knowledge, contributing to its growth in a crescent spiral - the learning spiral - that takes place as the user interacts with the computer to solve a particular project (Valente, 2002).

This learning spiral is a theoretical construct and does not mean that each action takes place one at a time and in the sequential order as was presented. However, the possibility of using ICT and of engaging learners in this learning spiral helps to create rich, flexible and optimal learning environments, in the sense of Csikszentmihalyi's flow theory (Csikszentmihalyi, 1990). The desire to have the project solved, the fast and faithful feedback provided by ICT constitutes a stimulating situation, challenging people's intellectual capacities. In this situation people can feel deeply immersed, learn a great deal, and feel empowered. This feeling of empowerment has been observed in different populations of different ages and capabilities, such as in special education (Valente, 1991), in regular school situation (Valente, 1993), with disadvantaged children (Valente, 1995b) and with the elderly (Valente, 2001).

However, as pointed out before, the teacher has a very important role in keeping the sequence of actions running so the learning spiral can happen. This means that the teacher needs to be prepared to know how to take advantage of each situation to help the knowledge construction process. This implies knowing about ICT and how to use it pedagogically.

\section{THE PROCESS OF PREPARING TEACHERS}

The process of preparing teachers should be based upon knowledge construction, through the learning spiral, as discussed above. These teachers should experience exactly what they will provide to their students. As 
mentioned by Torres (2001) nobody can promote development of something that was not developed in herself/himself. Thus, the objective is to help teachers to learn about ICT so they can integrate these technologies into their practice. The idea is not to deal with the content of their specific subject area but to allow the construction of the following types of knowledge that overlap and do not happen necessarily in this sequence:

- To understand the potentials of ICT as resources to construct new knowledge. This understanding will be constructed as the professional reflects upon her/his own learning experience using these technologies to develop their own projects;

- To know how to use ICT in pedagogical project activities. This implies two types of knowledge: one, about how to develop her/his own projects using these technologies; the other, about how to interact with learners and help them to develop their projects through the use of ICT;

- To know how to act with her/his own classroom. The knowledge the teacher is constructing has to be contextualized in the community in which s/he acts. This happens as the teacher works with her/his students, helping them to learn and to become better learners. Thus these teachers will learn how to be learning agents not only by thinking but by acting as learning agents;

- To understand her/his actions as learning agent. Each teacher has to reflect upon her/his performance as learning agent and to debug it. This has the function of helping the development of knowledge about learning, about the learner's style, about how to encourage the learner's reflective and critical capacities, and about how to promote social relations so that learners can learn from one another and can work cooperatively;

- To confront the teacher's approach with other teachers. This has the function of decontextualizing the knowledge the teacher has acquired in her/his community, broadening it, comparing pedagogical ideas with other teachers, understanding that there are many different ways of approaching a learning experience;

- To be aware of and to use lifelong learning ideas herself/himself and in her/his practice, integrating them into all the activities developed with other learners.

From this perspective, preparing teachers to be able to use ICT cannot be based upon courses to pass on information, but upon the establishment of learning spirals about these different types of knowledge. A specific learning experience is taking place with respect to each of these different types of knowledge. Each of these experiences has to be used as an object of 
reflection and of knowledge construction about technical and pedagogical issues, about learning and about lifelong learning.

Another component of this preparation strategy is that these teachers cannot be removed from their work place or interrupted in their classroom activities in order to learn. This would leave too many classrooms without teachers. The solution is an in-service training by creating a virtual learning environment, via the Internet. This will help teachers to become learning agents as well as create opportunities for them to become familiar with tools for continuing learning throughout their lives. They will not only be able to help other people to become lifelong learners but they will be lifelong learners themselves. However, the distance education approach used has to be one that emphasizes the process of knowledge construction.

\section{A DISTANCE EDUCATION APPROACH THAT ALLOWS KNOWLEDGE CONSTRUCTION}

The idea of the learning spiral has been used also to establish a methodology for distance education, via the Internet. Briefly, distance education has changed the temporal and spatial relationship between the learner and the source of information (teachers or printed material). Different media and possibilities made available by the Internet have changed the ways education is taking place today, creating real opportunities for lifelong learning independently of time and space.

In the Web it is possible to find courses that are based upon different educational methodologies, although they can be categorized in three major groups: broadcast, consisting of making information available by means of mass media such as TV, radio or Internet, with no interaction between users and provider; virtual school, on-line courses using a pedagogy that is very similar to what happens in a face-to-face classroom today, with a certain degree of interaction between users and provider; and the virtual learning environment (Valente, 1999b).

The virtual learning environment allows teachers and the course docent to be together, side by side, although via the Internet. It is highly interactive and the interaction teacher-docent is established in order for the docent to help the teacher to solve particular problems s/he encounters in her/his practice. Thus, in order to be effective in this course, the teacher must be engaged in a project or in a problem to be solved. For example, implementing ICT in her/his discipline or developing interdisciplinary projects with students involving other colleagues. In this situation $\mathrm{s} / \mathrm{he}$ is producing results and reflecting upon them. If a difficulty emerges, the 
teacher sends information (problem description, video, pictures) to the course docent. The docent reflects upon the information received and sends back questions, articles, and examples of activities or specific support material so the teacher can use this information to debug her/his project. New results can be obtained, new difficulties can emerge and the sequence of actions can be repeated.

These interactions take place not only between one teacher and the course docent, but all teachers can interact among themselves and with the docent. This helps to constitute a learner's network. Everybody can see and comment on everybody's work, exchange experiences, present different points of view for deeper levels of reflection. This network encourages collaborative work since learners can identify and jointly develop projects that have common backgrounds. At the same time it creates the conditions for the teacher to construct knowledge, fulfilling each participant's needs and interest. Each teacher can use her/his working reality as a context to know more and to improve her/his practice. Thus, the learning spiral is taking place at different levels and with respect to different types of knowledge being constructed (Prado \& Valente, 2002).

In this approach teachers' preparation happens without their leaving their work environment. In this sense, it creates the opportunity to bring work experience to the learning environment that is much more difficult in a faceto-face situation. However, this opportunity for higher quality learning does not happen without extra cost. The implementation of the virtual learning environment is much more costly than the broadcast or virtual school approaches. The course docent cannot effectively work with more than 20 learners and it is necessary to maintain a good team of experts to prepare support materials almost under demand.

\section{EXAMPLES OF TEACHER PREPARATION COURSES}

The process of preparing teachers to use ICT in their pedagogical activities, via the Internet, was carried out in two main courses in Brazil. These were Distance Education courses, to prepare teachers from special education and from basic education respectively, to be able to use ICT in their classroom activities. These on-line courses used the virtual learning environment approach, promoting the development of the reflective teacher, emphasizing reflection-in-action and reflection-on-action and working with contextualized and decontextualized knowledge. These different reflections and knowledge were elaborated at different levels: about technical aspects of ICT, about the use of ICT to develop their own projects, about how to use 
ICT with their students, and about the product of their learning process through discussion, via the Internet, with a larger audience and in great depth than is usually possible in a face-to-face situation.

One course was part of the Projeto de Informática na Educação Especial - PROINESP (Project of ICT in Special Education), sponsored by the Special Education Secretary from the Ministry of Education Office and by the National Federation of APAEs (FENAPAEs). The objective was to prepare special education teachers from $\mathrm{APAE}^{2}$ and other special education institutions in different regions in Brazil to be able to use ICT in their classroom activities.

The PROINESP course happened twice and the latest version was administered by two groups of docents, one from the Nucleus of Informatics Applied to Education from the State University of Campinas (UNICAMP) and the other from the Nucleus of Informatics in Special Education from the Federal University of Rio Grande do Sul (UFRGS). This was a 210-hour course, divided into two modules. One of 90 hours, involving face-to-face activities, taking place at the local participant's region, about introductory aspects of ICT (Windows operating system, Word and the Internet). Its objective was to give the participants the minimal knowledge necessary to be able to communicate via the Internet. The other module was a 120 -hour online course, about 12 weeks, via the Internet. At the end of the second module there was a three-day face-to-face seminar.

The 120-hour on-line course consisted of activities about the computer language Logo, the pedagogical uses of Internet, educational software available to special needs children, integration of different software in project development, devices to increase ICT accessibility and about the development of a plan regarding the use of ICT in the institution. The online course used the TelEduc ${ }^{3}$ e-learning system. Each teacher had to develop ICT activities individually and had to use ICT with her/his students.

There were 389 teachers enrolled in the course, from 95 institutions (four teachers from each institution), divided into 17 groups of about 23 teachers each. From this total, 344 (88.4\%) were approved, 11 (2.9\%) teachers could not finish the course because of technical damage to the Internet connection and $34(8.7 \%)$ did not accomplish the minimal requirements in the course and did not pass.

\footnotetext{
${ }^{2}$ APAE (Associação de Pais e Amigos dos Excepcionais) is a non-government organization of parents of special needs children.

${ }^{3}$ TelEduc is a distance learning environment for courses through the Internet. It is being developed jointly by the Nucleus of Informatics Applied to Education (Nied) and by the Institute of Computing (IC) of the State University of Campinas (Unicamp). It is a free software under the GNU - General Public License and its site is at teleduc.nied.unicamp.br/teleduc
} 
The three-day face-to-face seminar happened one week after the end of the on-line course and 121 teachers (from 72 institutions) attended it. They presented posters on the work they developed with their students during the course and work they did in terms of disseminating ideas about the use of ICT among their colleagues in their own institution. These posters were visited by docents present in the seminar and commented upon in plenary sections in order to help teachers to debug their pedagogical use of ICT, and to discuss ideas that had important pedagogical contributions and could be implemented in other institutions. The principle results of this course can be seen in the Project site (Proinesp, 2002).

The other course was part of the Graduate Program in Education: Curriculum, from Pontificia Universidade Católica de São Paulo (PUC-SP). Docents and graduate students of this Program administered the Curso de Especialização em Desenvolvimento de Projetos Pedagógicos com Uso das Novas Tecnologias, (Specialization Course ${ }^{4}$ on Development of Pedagogical Projects Using ICT) financed by the Programa Nacional de Informática ProInfo (National Informatics in Education Program) from the Secretary of Distance Education of the Ministry of Education. This was a 420 -hour course and its objective was to prepare teachers from secondary and high schools, from different regions in Brazil, to learn how to be able to know how to develop pedagogical projects using ICT.

This course was divided into three modules. The first, of 60 hours, involving face-to-face activities, taking place at the local participant's region, was about introductory aspects of ICT (Windows operating system, Word and Internet). Its objective was to give the participants the minimal knowledge necessary to be able to communicate via Internet. The second module was a 300-hour on-line course, about 8 months, via Internet and using the TelEduc e-learning system. For the third module of 60 hours the teacher had to develop a monograph, under the supervision of a course docent. This was a reflective analysis of the teacher's own learning throughout the course.

The 300-hour on-line course consisted of activities about the development of pedagogical projects using different open-ended software such as a word processor, the computer language Logo, an authoring system to create Web pages, and the combination of these. Also there were several opportunities to discuss theoretical topics and to reflect upon the student's practical experience, with the purpose of relating practical experience and theory. Each teacher had to develop ICT activities individually and had to use ICT with her/his students. Also the Specialization Course structure

\footnotetext{
${ }^{4}$ It is equivalent to a Master's program, except that the student does not have to prepare and defend a dissertation.
} 
requires that a student participates in at least $85 \%$ of the activities and in each activity the teacher needs to achieve a minimum of $70 \%$ to pass.

The second module of the course started with 44 teachers, divided into two groups, with 23 and 21 teachers respectively. From this total, 35 (79.5\%) were approved, 9 (20.5\%) teachers could not finish the course because of either technical damage to the Internet connection, other professional engagements preventing them from developing the course activities or idiom difficulties as in the case of 2 teachers from Chile and one from Argentine.

In both courses the pass rate can be considered very good compared with traditional distance education courses. Several factors may have contributed to this success. First is the fact that a teacher is part of a network involving other colleagues and docents, functioning as a support net. In this environment ties are created, making it almost impossible for the teacher to abandon the course. Second, the purpose of the course is for teachers to learn about ICT in order to implement these technologies into their school or special education institution. If s/ he fails, this can jeopardize a much larger project. Third, part of the teacher preparation is the work $\mathrm{s} / \mathrm{he}$ does with her/his students. This is another level of responsibility that contributes to the teacher's continuing the course. In many situations teachers have reported that if it weren't for these different hooks, they would have left the course.

On the other hand, the teachers who were able to successfully complete the course reported that, despite the amount of work they had to do and the fact that they had to become more active learners, the course was worthwhile. They were learning about ICT and how to integrate these technologies into their school practice as the product of a construction process. They were constructing knowledge about ICT and about pedagogical changes, and overcoming several obstacles so ICT could gradually be implemented in their school. The fact that they were taking a leading role in implementing ICT in their schools, using an up to date technology, and observing through the use of ICT that their students were learning and showing themselves to be much better learners than the teachers thought, provided an opportunity for these teachers to feel empowered. As several teachers mentioned, the course meant a lot to them and made a big impact in their lives.

\section{CONCLUSION}

Although the virtual learning environment is not a solution to reach thousands of teachers, as is the real demand for teacher preparation in Brazil, this approach is more effective regarding the kind of learning environment educators should experience and know how to set up for their students. In 
this environment learners have to change attitude and acquire knowledge not only about particular subjects but how to deal with tools and strategies that help them to continue learning.

Since the courses emphasize the development of reflective teachers and provide means for them to understand ICT activities as windows into peoples' thinking processes, teachers are acquiring means to interact with their students, discussing the concepts involved in their activities as well as how knowledge is constructed. These are the first steps in mastering important ideas about how to become lifelong learners and how to create learning situations to help their students to develop lifelong learning mindsets.

\section{REFERENCES}

Csikszentmihalyi, M. (1990). Flow: The Psychology of Optimal Experience. New York: Harper Perennial.

Freire, P. (1975). Pedagogy of the Oppressed. New York: The Seabury Press.

Papert, S. (1980). Mindstorms: Children, Computers and Powerful Ideas. New York: Basic Books.

Prado, M. E. B. B \& Valente, J. A. (2002). A Educação a Distância Possibilitando a Formação do Professor com Base no Ciclo da Prática Pedagógica. In M. C. Moraes (Org.), Educação a Distância: fundamentos e práticas (pp. 27-50). Campinas, SP: UNICAMP/NIED.

Proinesp (2002). http://www.nied.unicamp.br/ proinesp

Sussman, G. J. (1975). Computer Model of Skill Acquisition. New York: American Elsevier Publishing Company.

Torres, R. M. (2001). Itinerários Pela Educação Latino-Americana: Caderno de Viagem. Porto Alegre: Artmed Ed.

Valente, J. A. (1991). Liberando a Mente: Computadores na Educação Especial. Campinas, SP: Gráfica Central da UNICAMP.

Valente, J. A. (1993). Computadores e Conhecimento - Repensando a Educação. Campinas, SP: UNICAMP/NIED.

Valente, J. A. (1995a). Logo as a window into the mind. Logo Update, 4(1), 1-4.

Valente, J. A. (1995b) The use of computers with disadvantaged children in Brazil. In A. J. Artiles \& D. P. Hallahan (Eds), Special Education in Latin America (pp. 77-114). Greenwood's Editor.

Valente, J. A. (1999a). Computadores na Sociedade do Conhecimento. Campinas, SP: UNICAMP/NIED. English version retrieved from http://www.nied.unicamp.br/oea

Valente, J. A. (1999b). Diferentes Abordagens de Educação a Distância. Coleção Série Informática na Educação - TVE Educativa. Retrieved from http://www.proinfo.gov.br.

Valente, J. A. (2000). Criando Oportunidades de Aprendizagem Continuada ao Longo da Vida. Revista Pátio, IV(15), 8-12.

Valente, J. A. (2001). Aprendizagem continuada ao longo da vida: o exemplo da terceira idade. In Vitória Kachar (org.), Longevidade: um novo desafio para a educação (pp. 2744). São Paulo: Cortez Editora.

Valente, J. A. (2002). A Espiral da aprendizagem e as tecnologias da informação e comunicação: repensando conceitos. In M. C. Joly (Ed.), Tecnologia no Ensino: implicações para a aprendizagem (pp. 15-37). São Paulo: Casa do Psicólogo Editora.

Weir, S. (1987). Cultivating Minds: A Logo Casebook. New York: Harper \& Row Publishers. 